\title{
PERAN KEPEMIMPINAN KEPALA MADRASAH DALAM MENINGKATKAN DISIPLIN SHOLAT BERJAMAAH PESERTA DIDIK
}

\author{
Nurlayla Gaib ${ }^{1}$, Najamuddin Pettasolong ${ }^{2}$, Satria Koni ${ }^{3}$ \\ IAIN Sultan Amai Gorontalo \\ email: nurlaylagaib@gmail.com
}

\begin{abstract}
ABSTRAK
Permasalahan dalam penelitian ini adalah bagaimana peran kepemimpinan kepala madrasah dalam meningkatkan disiplin shalat berjamaah peserta didik di MA AlKhairaat Kota Gorontalo, Apa saja faktor pendukung dan penghambat peran kepemimpinan kepala madrasah dalam meningkatkan disiplin shalat berjamaah peserta didik di MA Al-Khairaat Kota Gorontalo. Adapun tujuan penelitian ini adalah untuk mengetahui bagaimana peran kepemimpinan kepala madrasah dalam meningkatkan disiplin shalat berjamaah peserta didik di MA Al-Khairaat Kota Gorontalo, Untuk mngetahui apa saja faktor pendukung dan penghambat peran kepemimpinan kepala madrasah dalam meningkatan disiplin shalat berjamaah peserta didik di MA Al-Khairaat Kota Gorontalo. Jenis penelitian ini tergolong jenis kualitatif dengan pendekatan yang digunakan adalah fenomenologis. Selanjutnya, teknik pengumpulan data yang digunakan melalui observasi, wawancara dan dokumentasi. Sedangkan teknik analisis data dilakukan melalui tiga tahapan, yaitu: reduksi data, penyajian data dan Penarikan Kesimpulan. Dari hasil penelitian yang diperoleh peran Peran kepemimpinan kepala madrasah dalam meningkatkan disiplin shalat berjamaah peserta didik di MA AlKhairaat kota Gorontalo, sudah diperankan dengan baik. Hal ini dilihat dari segi peran kepala madrasah sebagai manajer seperti melaksanakan perencanaan, pengorganisasian, pelaksanaan serta evaluasi semuanya sudah terlaksana dengan baik. Faktor pendukung dan penghambat Peran kepemimpinan kepala madrasah dalam meningkatkan disiplin shalat berjamaah peserta didik di MA Al-Khairaat kota Gorontalo adalah Karena MA Al-Khairaat adalah: 1) Karena MA Al Khairaat adalah madrasah yang berbasis pondok pesantren, jadi lingkungannya baik dari pihak guru maupun sarana prasarana sangat mendukung. 2) Penghambatnya yakni: pertama, Ketika sudah bel istirahat shalat peserta didik yang tinggal di luar asrama pulang ke kos atau rumah mereka, kedua, Tidak adanya dukungan dari orang tua siswa untuk menjalankan peran sebagai pemimpin di madrasah.
\end{abstract}

Kata Kunci: Peran Kepemimpinan Kepala Madrasah, disiplin Shalat Berjamaah

\section{PENDAHULUAN}

Menurut Ahmad Tafsir, tujuan pendidikan Islam adalah membentuk manusia muslim sempurna yang beribadah kepada Allah swt. Dalam mewujudkan tujuan tersebut, utamanya membentuk manusia yang beribadah kepada Allah, memerlukan peran yang 
besar dari madrasah dan orang tua peserta didik. Membentuk manusia yang beribadah kepada Allah memerlukan proses dan kedisiplinan baik di rumah maupun di madrasah. ${ }^{1}$ Tidak dapat dipungkiri lagi, tujuan diciptakan manusia di dunia ini adalah hanya untuk beribadah kepada Allah. Seperti dalam firman-Nya dalam QS. Adz-Dzariyat:56, yaitu:

Terjemahnya:

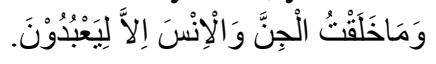

Dan aku tidak menciptakan jin dan manusia melainkan supaya mereka mengabdi kepada-Ku. ${ }^{2}$

Keberhasilan untuk mewujudkan tujuan-tujuan tersebut harus diperankan pemimpin lembaga pendidikan Islam di antaranya adalah kepala madrasah mempunyai peran yang sangat penting dalam mengkoordinir, menggerakkan dan menselaraskan sumber daya yang tersedia, manajemen kepala madrasah merupakan salah satu faktor yang dapat mendorong madrasah untuk mewujudkan visi, misi tujuan sasaran melalui program madrasah yang dilaksanakan terencana dan bertahap.

Dalam hal ini kepala MA Al Khairaat Kota Gorontalo sudah memenuhi tujuan pendidikan dan menjawab visi madrasah. Sesuai dengan visi MA Al Khairaat Kota Gorontalo yaitu terwujudnya SDM warga madrasah yang profesional, mandiri, religius dan berwawasan kedepan, kepala madrasah membuat program kedisiplinan shalat salah satunya adalah shalat zhuhur berjamaah.

Menurut Zurinal, disiplin adalah kunci sukses, sebab dalam disiplin akan tumbuh sifat yang teguh dan tekun dalam usaha maupun belajar. Pendisiplinan peserta didik dengan pelaksanaan ibadah merupakan langkah yang tepat. Karena ibadah merupan puncak segala kepatuhan, maksudnya adalah masih banyak orang muslim pada saat ini yang meninggalkan ibadah dan sering terlupakan. Maka bagi siapa yang melaksanakan karena telah menyadari pentingnya ibadah, disanalah bentu kepatuhannya terhadap allah swt. Itu ada pada diri seseorang tersebut. ${ }^{3}$

Di madrasah, peran kepala madrasah sangatlah dibutuhkan untuk menumbuhkan sifat disiplin kepada para peserta didiknya saat di madrasah. Pendisiplinan pada diri peserta didik sangatlah penting, karena dengan disiplin maka semua pekerjaan akan berjalan dengan baik. Yang dimaksud disiplin disini adalah kepatuhan untuk menghormati dan melaksanakan suatu sistem atau mentaati peraturan dan ketentuan yang telah ditetapkan tanpa pamrih.

Peran kepala madrasah yang dimaksud dalam penelitian ini adalah peran kepala madrasah sebagai manajer yang bertugas merencanakan, mengorganisasikan dan mengendalikan usaha anggota-anggota organisasi agar mencapai tujuan yang ingin dicapai. Kepala madrasah seharusnya dapat merencanakan program-program yang

${ }^{1}$ Zazin Nur, Kepemimpinan dan Manajemen Konflik: Strategi Mengelola Konflik dalam Inovasi Organisasi dan Pendidikan di Madrasah atau Sekolah yang Unggul, (Yogyakarta: Absolute Media, 2010), h. 55.

${ }^{2}$ Kementerian Agama, Al-Qur'an dan Terjemahnya, Surah Adz-Dzariyat ayat: 59.

${ }^{3}$ Rohiat, Manajemen Pendidikan: Teori Dasar dan Praktik, (Bandung: Refika Aditama, 2008), h.26. 
bersifat religius seperti shalat berjamaah agar kedisiplinan shalat berjamaah pada peserta didik meningkat.

Kondisi yang ada di lapangan menunjukkan masih terdapat beberapa peserta didik yang mengulur-ngulur waktu shalat dengan tidak segera berwudhu tetapi malah jajan dikantin dan ada juga peserta didik yang hanya bergurau dengan temannya di dalam kelas. Adapula peserta didik yang tidak khusyu' dalam sholat di tandai dengan bersenggolan dengan teman yang di sampingnya, bahkan ada peserta didik yang tidak melaksanakan sholat zhuhur berjamaah di masjid.

Dengan dijalankannya ibadah seperti sholat zhuhur berjamaah secara rutin, maka peserta didik akan menjadi terbiasa melaksanakannya dengan disiplin. Namun sebaliknya, jika kedisiplinan beribadah peserta didik di madrasah tersebut tidak baik atau lemah maka yang menjadi sorotan utama adalah kepala madrasah sebagai pemimpin madrasah tersebut. Untuk itu diperlukan manajemen yang baik dari kepala madrasah untuk mengatasi kedisiplinan shalat berjamaah bagi peserta didiknya.

\section{KAJIAN TEORI}

\section{Pengertian Kepemimpinan}

Kepemimpinan merupakan salah faktor yang sangat penting dalam suatu organisasi karena sebgaian besar keberhasilan dan kegagalan suatu organisasi ditentukan oleh kepemimpinan. Pentingnya kepemimpinan seperti yang dikemukakan oleh James M. Black pada manajemen: a guide to exclusive command dalam Sadili Samsuddin dengan kepemimpinan adalah kemampuan meyakinkan dan menggerakkan orang lain agar mau bekerja sama di bawah kepemimpinannya sebagai suatu tim untuk mencapai suatu tujuan tertentu. ${ }^{4}$ Kepemimpinan adalah upaya dalam memperbaiki dan meningkatkan mutu (kualitas) suatu instansi/madrasah yang tentu harus tau mengartikulasi visi, mewujudkan nilai dan menciptakan daya saing dan lingkungan yang kondusif guna mencapai sesuatu. ${ }^{5}$

Dengan demikian, dapat dipahami bahwa kepemimpinan adalah proses mempengaruhi tindakan orang lain, pemimpin adalah orang yang dipilih dan diakui memiliki sifat terpercaya, pengetahuan, keterampilan dan kemampuan dalam mempengaruhi orang lain sehingga di pilih atau disepakati dan diangkat sebagai pemimpin.

\section{PERAN KEPALA MADRASAH}

Peran kepala madrasah adalah suatu posisi atau jabatan pemimpin di sekolah dan mempunyai peranan yang sangat besar dalam mengembangkan mutu sekolah. Di samping itu, kepala madrasah memilih kemampuan mengelola sekolah, menghimpun, memanfaatkan dan menggerakkan seluruh potensi sekolah secara optimal untuk mencapai tujuan. Kepala madrasah juga merupakan aktor penting untuk meraih suatu keberhasilan dalam lembaga, oleh karena itu kepala madrasah di tuntut untuk dapat berperan aktif serta

\footnotetext{
${ }^{4}$ Sadili Samsuddin, Manajemen Sumber Daya Manusia, (Bandung: CV Setia, 2006), h.

${ }^{5}$ Gary Yuki, Kepemimpinan dalam Organisasi, (Jakarta: Prentice-Hall, 2001), h.4.
} 287. 
memberikan segala kemampuan yang dimiliki secara terus-menerus dan wajib untuk selalu meningkatkan kompetensinya sebagai pimpinan lembaga. ${ }^{6}$

\section{DISIPLIN SHALAT}

Berkaitan dengan disiplin shalat, pengertiannya diadaptasikan sebagai ibadah yang berupa ucapan dan perbuatan yang diawali dengan takbiratul ihram dan diakhiri dengan salam, dikerjakan sesuai dengan syarat-syarat tertentu, teratur dan dalam ketentuan jadwal shalat, atau aturannya. Seorang muslim yang shalat dianjurkan agar khusyu', merendahkan hati, memerhatikan sepenuhnya dengan serius, dengan penuh rasa takut, cemas dan penuh pengharapan karena berhadapan dengan Tuhan Yang Maha Agung dan Maha Besar. Berdisiplin shalat berarti seorang mushalli menjaga waktu-waktu shalat dengan baik, tidak lalai dan berdisiplin diri.

\section{METODOLOGI PENELITIAN}

Sesuai dengan metode penelitian dan permasalahan yang telah dipaparkan sebelumnya, penelitian ini merupakan penelitian kualitatif. Dalam penelitian kualitatif instrument penelitian adalah peneliti sendiri. Instrument penelitian tidak bersifat eksternal atau objektif, akantetapi eksternal atau subyektif yaitu peneliti itu sendiri tanpa menggunakan tes, angket maupun eksperimen. Oleh karena itu, kehadiran peneliti secara langsung merupakan keharusan dalam penelitian kualitatif. Penelitian ini dilakukan di Madrasah Aliyah Al Khairaat JL., Sultan Botutihe No. 16 Kec. Kota Utara, Kota Gorontalo. Lokasi ini penulis pilih sebagai objek penelitian, dengan alasan dapat dijangkau dan mudah mendapatkan data. Adapun Teknik pengumpulan data yang digunakan yaitu observasi, wawancara, dokumentasi dan triangulasi. Sedangkan untuk menguji keabsahan data yang telah didapat, peneliti menggunakan dua Teknik untuk menguji keabsahan data tersebut yaitu dengan triangulasi sumber dan triangulasi metode.

\section{HASIL PENELITIAN}

Hasil penelitian ini menunjukkan bahwa:

1. Peran kepemimpinan kepala madrasah dalam meningkatkan disiplin sholat berjamaah peserta didik di MA Al Khairaat kota Gorontalo, sudah menjalankan peran sebagai pemimpin dan manajer seperti melaksanakan (perencanaan, pengorganisasian, pelaksanaan serta evaluasi) dengan baik.

2. Faktor pendukung dan penghambat peran kepemimpinan kepala madrasah dalam meningkatkan disiplin sholat berjamaah peserta didik di MA Al Khairaat kota Gorontalo:

a. Faktor pendukung

Karena MA Al Khairaat adalah madrasah yang berbasis pondok pesantren, jadi lingkunganya baik dari guru-guru maupun sarana prasarana mendukung untuk menerapkan itu semua.

6 Sidik, Firman. "KONSEP PENGEMBANGAN KURIKULUM PENDIDIKAN ISLAM." (2016): 100-114. 
b. Faktor penghambat.

1. Ketika sudah bel istirahat sholat peserta didik yang tinggal di luar asrama pulang ke kos atau rumah mereka. Hal tersebut menjadi faktor penghambat mereka untuk tidak bisa mengikuti sholat berjamaah di masjid.

2. Tidak adanya dukungan dari orang tua peserta didik untuk menjalankan peran sebagai pemimpin di madrasah.

\section{DAFTAR PUSTAKA}

Gary Yuki, Kepemimpinan dalam Organisasi, Jakarta: Prentice-Hall, 2001

Kementerian Agama, Al-Qur'an dan Terjemahnya

Rohiat, Manajemen Pendidikan: Teori Dasar dan Praktik, Bandung: Refika Aditama, 2008

Sadili Samsuddin, Manajemen Sumber Daya Manusia, Bandung: CV Setia, 2006

Sidik, Firman. "KONSEP PENGEMBANGAN KURIKULUM PENDIDIKAN ISLAM." (2016): 100-114.

Zazin Nur, Kepemimpinan dan Manajemen Konflik: Strategi Mengelola Konflik dalam Inovasi Organisasi dan Pendidikan di Madrasah atau Sekolah yang Unggul, Yogyakarta: Absolute Media, 2010. 